\title{
Interminable Disagreement : Reflections on the Autonomy of International Organisations
}

Klabbers, Johannes Antonius Maria

2019-03-11

Klabbers , J A M 2019 , ' Interminable Disagreement : Reflections on the Autonomy of International Organisations ' , Nordic Journal of International Law , vol. 88 , no. 1 , pp. 111-133 . https://doi.org/10.1163/15718107-08810006

http://hdl.handle.net/10138/321523

https://doi.org/10.1163/15718107-08810006

unspecified

acceptedVersion

Downloaded from Helda, University of Helsinki institutional repository.

This is an electronic reprint of the original article.

This reprint may differ from the original in pagination and typographic detail.

Please cite the original version. 
Interminable Disagreement: Reflections on the Autonomy of International Organizations

Jan Klabbers ${ }^{1}$

I. Introduction

This paper aims to address the autonomy of international organizations in law and in normative debate generally, but will do so in unorthodox manner. In order to make the point that the autonomy of international organizations (from their member states) is strengthened by the way normative discussions tend to be structured, I will first need to provide an outline of the basic structure of normative debate - an outline that owes much, as cognoscenti will recognize, to the work of Alasdair Maclntyre. ${ }^{2}$ The general point then to emerge (but without being further investigated) is that the autonomy of international organizations is not so much directly a factor of the will of the organization or of its member states, but follows nigh-on inevitably from the structures of normative debate: such debates presuppose autonomy, and strengthen autonomy. In other words, achieving autonomy is not dependent on political intentions - not only, at any rate. Instead, I will argue that autonomy is achieved whenever international organizations are engaged in legal or ethical debate. This presupposes that I start with a brief and rough outline of how normative debate is structured.

Much ethical argument pits the two leading Western ethical approaches against each other, and much legal argument follows the same pattern. Much normative argument consists of an oscillation between deontological and consequentialist approaches. ${ }^{3}$ This is probably no surprise: deontology and consequentialism are both children of the Enlightenment, ethical theories isolated from any social or historical anchoring but based on conflicting yet complementary assumptions about human behavior. The result is that moral disagreement and ethical debate remain interminable, not merely because they go on and on but, more fundamentally, as Maclntyre once suggested, because 'they apparently can find no terminus.' ${ }^{4}$

Perhaps the best example, highly topical in 2017/2018, is the \#metoo discussion, sparked by accusations of sexual harassment against film producer Harvey Weinstein and followed by many similar accusations in the film industry, academia, and elsewhere. The most serious response to date consists of an open letter to the French newspaper Le Monde, signed by a hundred or so women active in the same fields of occupation. So how is this debate structured?

Weinstein's prosecutors and others suggest, mostly, that all sorts of rules, written and unwritten, have been broken. They suggest that acts of harassment have been many, and are typically linked to a power imbalance: many of the accused are powerful men, while many of the victims are relatively powerless: young women aspiring to become actors, or academics, and sometimes young boys with similar aspirations. Sexual

${ }^{1}$ Dr J. Klabbers is Professor of International Law at the University of Helsinki.

2 See Alasdair MacIntyre, After Virtue: A Study in Moral Theory, 2d edn (London: Duckworth, 1985).

${ }^{3}$ This chimes with Fletcher's observation that much ethical debate is actually methodological in nature, with substance following from method. See Joseph Fletcher and John Warwick Montgomery, Situation Ethics (Minneapolis MN: Dimension Books, 1972), at 18.

${ }^{4}$ See Maclntyre, After Virtue, at 6. 
harassment is illegal, so the claim goes, and in violation of all sorts of standards, the sorts of standards that all of us know, and which are linked to blackmail ('Have sex with me otherwise you won't get that promising film role'), power abuse, and similar issues. In doing so, the tone of the accusation is mostly deontological: the acts of the accused are bad because they go against our rules.

By contrast, the tone of the letter to Le Monde is different: it focuses not so much on whether or not any rules have been broken, but on the consequences of making allegations and accusation that rules have been broken. Even if the allegations are true, so the letter suggests, the consequences are dire: the \#metoo movement is creating a new climate of sexual puritanism, in which some men have already been victimized by having been falsely accused of harassment. ${ }^{5}$ In emphasizing the consequences of the \#metoo campaign, the letter writers (a large group of women, said to include author Catherine Millet and film star Catherine Deneuve) adopt a consequentialist approach.

The problem that transpires then is that both groups talk past each other: their approaches are incommensurate. The \#metoo campaign taps into a deontological logic, and for whatever such a logic is worth, it is often vulnerable to consequentialist critiques precisely because deontological arguments typically do not focus on consequences: what matters is that rules have been broken - this is considered bad enough in its own right, regardless of the consequences. By contrast, the Le Monde letter writers tap into a consequentialist logic, emphasizing how undesirable the consequences are, both for individuals who have stood falsely accused, and for society at large (by invoking what they call 'the new puritanism'): the world will be a worse place. It is no surprise though that such an approach is often susceptible to a deontological critique, precisely because to the consequentialist it is not all that relevant whether rules have been broken - and it is no coincidence that responses to the Le Monde letter keep insisting on rules having been broken, meeting a consequentialist argument with a deontological critique.

Whether consciously or subconsciously, the parties to the debate both realize that their own premises render them vulnerable to comments from the opposite camp, so they do their best to cater to the other approach. The Le Monde letter, while consequentialist in tone, nonetheless acknowledges that rules exist and have been broken: opening up the discussion and bringing instances of harassment to the fore was considered necessary but, so they insist, the movement is now going too far or turning against itself. And while some men have clearly broken those rules, one should acknowledge that the rules are open to differing interpretations: there is a difference between flirting or clumsy pick up attempts on the one hand, and harassment on the other.

For its part, the \#metoo movement too is not blind to consequences: it not only insists on rules being broken, but additionally it promises a world free of harassment as a consequence of the campaign, as well as justice for those who have been victimized. Thus, while it starts from deontological premises, it pays homage to consequentialism by pointing to the possible results of a though campaign: the world will be a better place. In short, the \#metoo debate oscillates between deontology and consequentialism. Rules are acknowledged to exist by both parties, but differently interpreted; consequences are envisaged by both parties, but differently emphasized. As a result, the debate seems interminable and unsolvable, and it may be hypothesized that a

\footnotetext{
${ }^{5}$ The letter was published in Le Monde, 9 January 2018. I was able to access part of it; the rest was behind a paywall, so I have had to rely on reports by others about some of its contents. While my reconstruction thus may miss a few nuances, I nonetheless do not believe that it is affected to such an extent as to become implausible or incorrect.
} 
reasonable conclusion will be difficult to find as long as the protagonists remain enclosed in a circle of deontology and consequentialism. ${ }^{6}$

What applies to ethical debate generally also applies to debate concerning international organizations, whether ethical or legal in nature (and the two are often difficult to distinguish to begin with). International organizations are analytically involved in three types of legal relations. ${ }^{7}$ First, there is the relationship between the organization and its member states, to which the dominant approach is a functionalist approach. Second, there is the internal dimension: the organization relates in one way or another to its staff members, and its organs stand in some kind of relationship to each other. And third, there are the relations with the outside world: with third states or organizations, with civil society, with individuals. I will discuss examples of ethicallegal debate from all three settings, and will aim to discuss whether and if so that what extent the autonomy of international organizations is a function of the way these debates take place. I use 'autonomy' in a fairly broad sense, which seems fully justified by the consideration that this paper is a first attempt to think about autonomy as a function of the debates in which organizations are engaged, rather than as a variable influenced by power political considerations or material interests. ${ }^{8}$ With a little more precision, I will presume that the autonomy of international organizations is connected to what may be called 'moral autonomy', a broader concept applicable to states, organizations and individuals alike, and fundamental to much legal and ethical debate. Another way of referring to moral autonomy is to speak of 'freedom': the freedom to act without constraints, except constraints that are self-imposed, precisely by virtue of the moral autonomy of the actors. In less abstract terms, I will assume that our everyday conception of the relevant actors is that they are free to act as they please, unless they have consented to something else. It seems to me that this assumption is fairly uncontroversial, but I will not engage in an attempt to defend it.

Some further preliminary comments are in order. In what follows, I will use legal debate as a proxy for ethical debate. I realize law and ethics are not identical (this will become clear especially towards the end of the paper), but they are not unrelated either, and at any rate, for present purposes the distinction is not particularly relevant. ${ }^{9}$ By the same token, I will not distinguish between ethics and morality, partly because there are many ways of making this distinction ${ }^{10}$, and partly because, again, for present purposes nothing hinges on the distinction.

Neither will I focus on whether autonomy can be said to be a principle of international organizations law. For one thing, a strong argument can be made that there is no such thing as a separate corpus of rules and

\footnotetext{
${ }^{6}$ Academic lawyers may recognize this sort of conclusion as being influenced by how critical legal studies has analyzed the structure of legal argumentation. See in particular Martti Koskenniemi, From Apology to Utopia: The Structure of International Legal Argument (Helsinki: Finnish Lawyers' Publishing Company, 1989).

${ }^{7}$ See Jan Klabbers, 'Theorising International Organisations', in Anne Orford and Florian Hoffmann (eds.), The Oxford Handbook of the Theory of International Law (Oxford University Press, 2016), 618-634; in greater detail Jan Klabbers, 'The EJIL Foreword: The Transformation of International Organizations Law', (2015) 26 European Journal of International Law, 9-82.

${ }^{8}$ Nonetheless I will look at autonomy predominantly as it manifests itself vis-à-vis member states, rather than with respect to other actors. On autonomy, a pioneering volume is Richard Collins and Nigel D. White (eds.), International Organizations and the Idea of Autonomy: Institutional Independence in the International Legal Order (Abingdon: Routledge, 2011); see also Jan Klabbers, 'Transforming Institutions: Autonomous International Organisations in Institutional Theory', (2017) 6 Cambridge International Law Journal, 105-121.

${ }^{9}$ See generally also Peter Cane, Responsibility in Law and Morality (Oxford: Hart, 2002).

${ }^{10}$ See only the brief overview in James Laidlaw, The Subject of Virtue: An Anthropology of Ethics and Freedom (Cambridge University Press, 2014), 110-119.
} 
principles to be referred to as international organizations law. Typically, organizations have their own legal order, and to the extent that they interact with others, they are subjected to general international law (or, on occasion, domestic law). ${ }^{11}$ It is no coincidence that no one speaks of the 'rule' or 'principle' of implied powers, but that talk is of the doctrine of 'implied powers': a solution valid in organization $\mathrm{X}$ is not by definition and extension valid for organizations $Y$ and $Z$. Heuristically, for purposes of teaching and discussion, all these doctrines and existing rules relating to specific organizations may be viewed as international organizations law; for legal purposes, however, conclusions drawn with respect to one organization cannot without more be transplanted to other settings. ${ }^{12}$ Hence, there is little to be gained by concentrating on whether there exists a principle of autonomy in international organizations. Instead, the focus will rests on how institutional autonomy is stimulated by legal debate, and can be regarded as the inevitable consequence thereof.

The paper will be structured as follows. I will discuss three incidents relating to the three different kinds of legal relations that international organizations can entertain: with their member states (the proposed expulsion of Liberia from the League of Nations), their staff (McCarthyism in UNESCO), and the external world (the infamous Haiti cholera affair in which the UN has been embroiled). The three vignettes not only involve different legal relations and legal issues, they also involve different international organizations, and involve different time frames; together they provide a picture of patterns repeating themselves regardless of time and place. This will be followed by a discussion of how the practice of legal and ethical argument affects the autonomy of international organizations.

II. The Organization and its Members: Liberia's Proposed Expulsion from the League of Nations ${ }^{13}$

Liberia was among the original members of the League of Nations, having declared itself to be on the side of the Allied Powers during World War I. As such, it was automatically entitled to join the League, regardless of whether it met the League's requirements for membership - Liechtenstein found out, to its dismay, that membership of the League was not always and automatically granted to applicant states. ${ }^{14}$

Liberia's fitness for membership would come to be questioned though from the late 1920s onwards, when it became abundantly clear that slavery and compulsory labour were widely practiced in Liberia ('a system hardly distinguishable from slavery', as Eden put it ${ }^{15}$ ), and in particular after reports came in about mistreatment of members of the Kru tribe (actually a group of related tribes) by government forces. Several reports commissioned by the League confirmed as much, and by 1934 the United Kingdom raised the possibility of

\footnotetext{
${ }^{11}$ Jan Klabbers, 'The Paradox of International Institutional Law', (2008) 5 International Organizations Law Review, 151-173.

${ }^{12}$ The International Court of Justice attempted to do something along these lines in 1996: see Legality of the Use by $a$ State of Nuclear Weapons in Armed Conflict, [1996] ICJ Reports 66. For commentary, see Jan Klabbers, 'Global Governance at the ICJ: Re-reading the WHA Opinion', (2009) 13 Max Planck Yearbook of United Nations Law, 1-28.

${ }^{13}$ The general narrative here follows Konstantinos D. Magliveras, Exclusion from Participation in International Organisations: The Law and Practice behind Member States' Expulsion and Suspension of Membership (The Hague: Kluwer, 1999), 7-21; see also Alison Duxbury, The Participation of States in International Organisations: The Role of Human Rights and Democracy (Cambridge University Press, 2011), 107-109.

${ }^{14}$ This would change with the UN, resulting in some lamenting that the UN has become too welcoming: see Thomas D. Grant, Admission to the United Nations: Charter Article 4 and the Rise of Universal Organization (Leiden: Martinus Nijhoff, 2009).

${ }^{15}$ Eden spoke at the Council, 18 May 1934, League of Nations Official Journal, June 1934, at 509.
} 
Liberia's expulsion. Things never got quite that far: the most far-reaching motion tabled in the League Council was devoted to withdrawing an assistance plan. Nonetheless, the argumentation was revealing. ${ }^{16}$

Already prior to the Liberia episode, the League had discussed the legal regime relating to expulsion, in light of the indeterminate nature of the pertinent provision, i.e. the fourth paragraph of Article 16 of the Covenant. This held that 'Any Member of the League which has violated any covenant of the League may be declared to be no longer a Member of the League' after a unanimous vote of all other members represented on the Council. Much of that discussion revolved around the 'de minimis' question. As the provision spoke of 'violation' pure and simple, without qualification, an argument could be made (and was made by commentators) that literally any violation, no matter how irrelevant, could be ground for expulsion. The Council itself argued differently though, suggesting the relevance of a principle of proportionality: surely, in some cases, expulsion would serve no purpose of the League and merely be counter-productive. ${ }^{17}$

The possibility of expulsion was raised in the aftermath of discussions about assistance through the UK representative, Anthony Eden. ${ }^{18} \mathrm{His}$ argument was clear, and tapped into deontological reasoning. To Eden's mind, in particular the mistreatment of the Kru tribes amounted to a violation of the rule contained in article 23 of the Covenant, in particular the obligation 'to secure just treatment of the native inhabitants' of territories under member state control contained in paragraph (b) of Article 23. This in itself would be sufficient to trigger the expulsion clause of Article 16. Liberia countered ${ }^{19}$ by suggesting that the evidence on which the UK based itself might be less than compelling and could have been tainted by political considerations, therewith effectively denying that any violation had taken place.

Both also, however, hinted at consequentialist arguments. For the UK, it was clear that expulsion would not in itself 'assist towards a solution of the Liberia problem', but this was simply a case of such magnitude that it could not be passed over in silence: Eden spoke of 'gross maladministration', a 'real tragedy', and the suggestion, carefully phrased, was that the League should not offer a veneer of respectability to a state with am 'unrelieved record of misery and misgovernment'. ${ }^{20}$ And while Eden did not mention it before the League, reportedly debates in the British House of Lords suggested that the UK was rather worried about the possible spread of epidemic diseases, mismanaged by Liberia's authorities, to neighbouring British territories. ${ }^{21}$ Liberia, for its part, suggested in a consequentialist vein that much of the fighting had been 'inter-tribal', and if there had been government action it had been fully justified due to the threat of Kru colonies from neighbouring countries, who were either making efforts to join the fighting or tried to smuggle in arms and ammunition to supply Liberia's tribes in their fight against the government. ${ }^{22}$

\footnotetext{
${ }^{16}$ For background on the role of the Firestone Company in Liberia, see the excellent study by Doreen Lustig, Facilitative Failures: International Legal Regulation of Private Business Corporations, 1886-1981 (Oxford University Press, forthcoming).

${ }^{17}$ See the discussion in Magliveras, Exclusion from Participation, esp. 15-18.

${ }^{18}$ See League of Nations Official Journal, June 1934, 509-511.

${ }^{19}$ See League of Nations Official Journal, June 1934, 512.

${ }^{20}$ Eden speaking at a Council meeting, 18 May 1934, in League of Nations Official Journal, June 1934, 509-511. The quoted words can be found at 511 .

${ }^{21}$ This is mentioned in a contemporary commentary by Georg von Gretschaninow, 'Der Versuch eines Ausschlussverfahrens gegen Liberia nach Art. 16 Abs. 4 der Völkerbundssatzung', (1935) 5 Zeitschrift für ausländisches öffentliches Recht und Völkerrecht, 174-178, at 175.

${ }^{22}$ Reply from the Government of Liberia, 26 March 1934, in League of Nations Official Journal, June 1934, 571-572, at 572.
} 
Again then, both sides utilized deontological as well as consequentialist argument. The deontological argument revolved around whether article 23(b) of the Covenant had been violated, with the UK arguing that it had and Liberia instead claiming that the allegations were 'a pure invention', and part of a 'propaganda campaign'. ${ }^{23}$ As for the consequentialist part, the UK suggested there should be no place in the League for a state such as Liberia; the League was not supposed to harbour criminal governments, and allowing Liberia to stay inside would set an unhappy precedent ${ }^{24}$; Liberia, in turn, downplayed the allegations, and justified them by pointing to external circumstances: they were necessary to prevent further escalation due to the involvement of foreign sympathizers.

\section{The Organization and its Staff: McCarthyism in UNESCO}

The post-war surge in the number of international organizations was quickly followed by the outbreak of the Cold War, and it should come as no surprise that international organizations too became the site of Cold War struggles. One particularly well-known manifestation was the crusade launched by Senator Joseph McCarthy, so well-known that 'McCarthyism' has become a by-word for witch hunts. McCarthy questioned the loyalty of American citizens suspected of communist citizens, and while some of targets were film starts, directors and other inhabitants of Hollywood, his work also affected international organizations. ${ }^{25}$ International civil servants with American citizenship were often asked to make public or discuss their convictions or sympathies, and the US government set up an International Organisations Employees Loyalty Board, which sent questionnaires and invited international civil servants of US provenance to state their loyalties.

Many must have complied, but some did not. Within the UN itself the bouts of McCarthyism took a quite dramatic turn in the autumn of 1952, which would eventually lead to the creation of the above-mentioned Loyalty Board. ${ }^{26} \mathrm{~A}$ number of individuals were summoned to appear before the Internal Security Subcommittee of the US Senate Judiciary Committee, and eighteen of them pleaded the Fifth Amendment, containing the right against self-incrimination. Secretary-General Trygve Lie responded by dismissing the individuals who had a temporary contract with the UN; those with a permanent contract were placed on compulsory leave, and an international commission of jurists was established to see what further action could be taken.

In the process, judging by his memoires Lie's defense was twofold. First, he pointed out that what he consistently referred to as the privilege against self-incrimination (as opposed, probably, to a right against selfincrimination ${ }^{27}$ ) was in clear violation of the Staff Rules, adopted by the UN General Assembly, and in particular

\footnotetext{
${ }^{23}$ Letter from the Permanent Delegate of Liberia to the Secretary-General, 13 April 1934, in League of Nations Official Journal, June 1934, at 570 .

${ }^{24}$ Admittedly, the argument was not made very explicitly, but often enough mere hints suffice.

25 This even made its way into contemporary belletrie; Shirley Hazzard's collection of related short stories, People in Glass Houses (London: Picador, 2004 [1967]), is set at the secretariat of a large international organization (referred to as the Organization, with Orwellian precision), where conformism reigns supreme.

${ }^{26}$ This is based on Trygve Lie, In the Cause of Peace: Seven Years with the United Nations (New York: MacMillan, 1954), esp. 395-400.

27 The Fifth Amendment itself uses neither term, and is framed in the negative: no person 'shall be compelled in any criminal case to be a witness against himself ...'. Jurisprudentially this suggests a right rather than a privilege.
} 
Article 1.4 thereof. ${ }^{28}$ Moreover, by joining the international civil service, the employees had waived whatever constitutional rights they may otherwise have enjoyed in the US. ${ }^{29}$ Second, he was clearly worried that the attitude of those eighteen individuals 'imperiled the position of the Organization in the host country' ${ }^{30}$, and speaks of public opinion in the US not being favourable towards the UN 'while the morale of the Secretariat slumped badly. ${ }^{31}$ The former is a deontological argument, referring to rules and duties; the latter is a consequentialist argument. Lie's memoires do not reveal exactly how the eighteen argued, but invoking the Fifth Amendment in itself suggests appealing to a right not to be coerced into anything, possibly backed up by the classic notions of freedom of conscience, of expression, of assembly. Whether the eighteen made any consequentialist argument is unknown, but one can easily imagine that they must have made reference to the consequences of an organization such as the UN giving in to political pressure from its host state.

McCarthyism also reared its head, with more extensive argumentation available, within UNESCO, an international organization based in Paris. Several employees of UNESCO had been asked to fill out a questionnaire relating to communist sympathies and had been summoned to explain themselves before the US Embassy in Paris. Upon their refusal to do so, their contracts were terminated, despite having earlier received notice that appointments were to be continued. Four of them seized the Administrative Tribunal of the International Labour Organization (ILOAT), including Mr Peter Duberg, and the Tribunal found unequivocally in their favour, ordering the decisions not to extend any contracts to be rescinded. ${ }^{32}$ UNESCO was unhappy with the result and went to the International Court of Justice, a facility which at that time was still extant. The ICJ, however, found that ILOAT had in no way overstepped its competences, and that the validity of ILOAT's decisions should be upheld. ${ }^{33}$

The arguments invoked back and forth will seem familiar. UNESCO relied on the same article 1.4 of the Staff regulations that was relied on by Trygve Lie some time earlier, and the behavior of Duberg and others was considered 'incompatible with the high standards of integrity' required from UNESCO employees. ${ }^{34}$ Moreover (and here consequentialist thinking was introduced in addition to duty-based thought), the behavior of Duberg and others was 'capable of harming the interests' of UNESCO. ${ }^{35}$

\footnotetext{
${ }^{28}$ He does not exactly explain how article 1.4 would be violated. On its face, this was a fairly sterile injunction on members of the Secretariat to behave appropriately, 'befitting their status', and not engage in any activity incompatible with the proper discharge of their duties. In particular, they should steer clear of political utterances, and one can only surmise that invoking the Fifth Amendment was construed in itself to be a political utterance, providing cause for dismissal. Lie's claim that the eighteen had 'gravely and irresponsibly transgressed the Staff Regulations' (see Lie, In the Cause of Peace, at 396) seems a little over the top, though. The Commission of Jurists would find, astonishingly, that pleading the Fifth Amendment amounted to an admission of guilt, since otherwise the Fifth Amendment would have been relied on without cause. Hence, in the Commission's view the dismissals were fully justified. The relevant paragraph of the report is cited in 'Secretariat', (1953) 7 International Organization, 128-130, at 129.

${ }^{29}$ See Lie, In the Cause of Peace, at 396.

30 Ibid., at 397.

31 lbid., at 397.

32 The ILOAT has jurisdiction over the staff disputes emerging in a number of international organizations, including UNESCO. The four disputes were handled separately by ILOAT, but followed similar patterns. What follows will be culled from Judgment No. 17, In re Duberg (26 April 1955). The Director-General of UNESCO at the relevant time was a US citizen, Mr Luther Evans.

${ }^{33}$ See Judgments of the Administrative Tribunal of the International Labour Organisation upon Complaints Made Against the United Nations Educational, Scientific and Cultural Organization, advisory opinion, [1956] ICJ Reports 77.

${ }^{34}$ See In re Duberg, sub chapter 'On the Substance', consideration A.

35 Ibid.
} 
Mr Duberg's arguments however, as rendered by ILOAT, were clearly considered to be more forceful. The same article 1.4 of the Staff Rules was held to clearly recognize freedom of conscience with respect to both philosophical convictions and political opinions (the deontological argument) ${ }^{36}$; any other understanding, so ILOAT suggested, would wreak havoc: if other member states would start to do the same, it would be 'liable to provoke disturbances in the international administration' (the consequentialist argument). ${ }^{37}$

ILOAT also invoked additional points, e.g., making clear that the Director-General of UNESCO was under a legal obligation not to receive instructions from any Government ${ }^{38}$, and that even if officials would have to abstain from propaganda or proselytism, this flowed from the 'overriding interest of the international organization to which they owe their loyalty and devotion' ${ }^{39}$; in other words, the duty to abstain from political activism did not owe anything to national loyalties. Either way, the behaviour of Mr Duberg in no way suggested that he had placed his own interests above the 'true interest' of UNESCO, which consists 'above all in safeguarding erga omnes its independence and impartiality'. ${ }^{40}$

The structure of the argument is familiar. UNESCO invokes a legal rule (article 1.4 of the Staff Rules), combined with the interest of the organization. Mr Duberg suggests (and ILOAT agrees) that the legal rule is wrongly interpreted and that instead the relevant consideration is a different rule (freedom of conscience, less explicitly to be found in an applicable legal rule), in conjunction with a different conception of the interest of the organization. The organization's interest is not best served by toeing the line of powerful member states, but instead by adhering strictly to independence and impartiality. On both sides, deontological and consequentialist arguments are used; no argument can be without.

IV. The Organization and the Outside World: Cholera in Haiti and the UN

Much the same logic also presents itself in relations between organizations and third parties, i.e. states, entities or others not directly related to the organization, including individuals. When international organizations were first created, in the late nineteenth century, the unspoked assumption was that their acts would only relate to their member states, and only to those states qua states. Organizations were not supposed to act autonomously in relation to other states, let alone other organizations, and their acts could, at best, only affect their member states in their capacity as member states: the populations of those member states would never be directly affected.

It is doubtful whether this assumption was ever plausible, and it is clear that it has lost whatever degree of plausibility it may once have possessed: the acts of international organizations affect individuals in their member states, sometimes indirectly, sometimes also very directly. Surely, when the UN imposes individual sanctions, those individuals are affected. Surely, when the ILO sponsors labour conventions, individuals are affected. Surely, when the World Bank sponsors an infrastructure project, individuals are affected. And surely, when the UN sends peacekeeping troops to trouble spots, individuals are affected. And it is no good to claim, in

${ }^{36} \mathrm{Ibid}$., sub chapter 'On the Substance', consideration B.

${ }^{37} \mathrm{Ibid}$., sub chapter 'On the Substance', consideration E.

$38 \mathrm{lbid}$

${ }^{39} \mathrm{Ibid}$., sub chapter 'On the Substance', consideration B.

${ }^{40} \mathrm{Ibid}$., sub chapter 'On the Substance', Consideration F. 
such cases, that those individuals have consented to be affected: this can be maintained with respect to member states (who join an organization of their own volition) and staff members (who opt to work for the organization), but not with respect to individuals who are subjected to an organization's executive or operational activities. ${ }^{41}$ And this is relevant, as expressing consent has an ethical value in and of itself: if one consents to being treated in a particular manner, one can hardly complain about it, unless the manner of treatment differs from that what has been consented to. ${ }^{42}$

So, what happened in Haiti? After the 2010 earthquake, the UN, which already had a presence on the island, sent in additional troops, including a contingent of peacekeepers from Nepal. Thereafter, cholera broke out in Haiti, for the first time in a century, and the suspicion arose that the cholera strains had been brought by Nepalese peacekeepers. ${ }^{43}$ It is not entirely clear whether these had been tested prior to deployment: the UN's internal manuals provide for health checks in a three-month period before deployment, and there is no strong evidence that this has been circumvented. The health checks are the responsibility of the sending state, but need to be validated by the UN itself, and it seems that this is what has happened. Assuming this is accurate, the problem is not one of wanton neglect of prescribed procedures, but of a most unfortunate collision of circumstances: it is not at all impossible that prospective peacekeepers were duly checked, but contracted the disease in the period between being checked and being deployed.

Either way, additional factors may well play a role, an important one being the decision to outsource waste management to a local Haitian company. In an attempt to do things without incurring huge costs (and placate the UN's donors), the assignment went to the company which came up with the cheaper bid and thus received the tender to install waste management facilities near the camp. To little avail, it transpired: human faeces were seen floating in Haiti's main river, the same river used for bathing and laundry purposes.

The episode raises a host of ethical questions, some related to the health checks on peacekeepers and the attribution of responsibility when things go wrong; some others are related to the ethics of insisting on getting the private sector involved and securing cheap put possibly inadequate services. And yet other issues relate to the aftermath: while it is clear that something dreadful happened on the UN's watch (regardless of whether blame can actually be attributed to the UN), the UN until December 2016 refused to issue an apology, and even then apologized for 'not doing enough' with respect to the outbreak of cholera and attempts to stop it, still stopping some way short of accepting any responsibility for the outbreak itself. ${ }^{44}$ Ironically - a rather sad irony - this may owe something to legal considerations, with the UN leadership fearing that an apology will be used against it in court.

For the events have reached the US courts, with victims and relatives aiming to sue the UN for damages. So what are the arguments? Much of the legal argument before the Southern District Court in New York revolved around the questions of immunity: under the UN Charter and related instruments, the UN invokes immunity

\footnotetext{
${ }^{41}$ Things are different with individuals providing services or selling goods to organizations, but this need not detain us here.

${ }^{42}$ This is well illustrated by the way consent is considered relevant to the management of large bureaucracies these days: whenever I am to enter a Helsinki University website to do my work (mark a thesis, e.g.), I am asked whether I consent to my personal details being made available to the same University - which, as my employer, already has that information at any rate... If I fail to consent, moreover, I am refused access to the thesis I am supposed to mark - so much for voluntarism.

${ }^{43}$ For a fine overview, see Jonathan M. Katz, The Big Truck that went By: How the World Came to Save Haiti and Left behind a Disaster (New York: Palgrave MacMillan, 2013).

${ }^{44} \mathrm{http}: / /$ www.un.org/apps/news/story.asp?NewsID=55694\#.WldUSmeONVY (visited 11 January 2018).
} 
from suit, with some of the victims claiming that an exception ought to be made in cases involving third parties. Thus, it was argued that the UN's indifference to the plight of Haitians 'is inconsistent with international law, inconsistent with human rights obligations of the United Nations, inconsistent with the U.N.'s own understanding of its obligations, and inconsistent with the U.N.'s institutional practice'. ${ }^{45}$ Instead, what the UN should do, is to offer access to justice through setting up some form of arbitration mechanism and, so the argument continued, this is precisely what would be prescribed by section 29 of the 1946 General Convention on the Privileges and Immunities of the United Nations in 'disputes of a private law character'.

The focus of the litigation thereby became the question whether the United Nations had been obligated to set up a special mechanism for settling any possible claims arising out of the cholera affair. Proponents argued in favour under reference to the wording of section 29 (a deontological argument) in conjunction with a hint to a more consequentialist argument. The grant of immunity in the 1946 General Convention had been based, so the proponents claimed, on a bargain: in exchange for immunity, the UN would set up alternative mechanisms for disputes of a private law character. ${ }^{46}$ Since the UN had not done so, it could not now invoke immunity - it had not kept its side of the bargain. And while the applicants did not develop the argument much further, they did not need to, as their message was clear: surely, the UN should not be allowed to get away with not keeping its side of the bargain.

Defendants raised, as was to be expected, opposing arguments, claiming absolute immunity from suit for the UN, only to be lifted by an explicit waiver. This too relied on the text of the 1946 General Convention: section II lists the necessity of an explicit waiver in no uncertain terms. And as with the applicants' argument, a more consequentialist argument needed merely to be hinted at: the UN's immunity has always been premised on a functionalist logic, something to the effect that without immunity, it would be impossible for the UN to function properly.

\section{A Principle of Autonomy}

Now what do these three vignettes suggest with respect to autonomy? The argument is, in essence, straightforward, and comes in two steps. First, with the arguments being structured as suggested, the ontological existence of the organization is taken for granted. When the UN is sued over acting in Haiti, no one questions the existence of the UN. When the UN or UNESCO are sued by staff members, no one questions the existence of the UN, or its raison d'être. Joseph McCarthy, to put it starkly, wanted to free the UN from communist sympathizers, but his mission was not to close down the UN. He could have proposed various alternatives: he could have proposed that the UN be dissolved; he could have proposed that it would be

\footnotetext{
${ }^{45}$ See Delama Georges and Others v United Nations and Others, transcript, October 23, 2014, at 37 (Muneer Ahmad, speaking on behalf of an amicus curiae group). Much of what follows is culled from the transcript and from the order of District Judge J. Paul Oetken, in Delama Georges and Others v United Nations and Others, 13-CV-1746 (JPO), dated 9 January 2015 (both on file with the author).

${ }^{46}$ In actual fact there is very little (if any) evidence that such a bargain was made while the 1946 General Convention was concluded. The text of the Convention does not support such a reading, although it also does not provide an insurmountable obstacle.
} 
removed from US soil; he could have proposed that the UN withdraw from the organization - but he proposed neither of these alternative courses of action, not even with respect to UNESCO. ${ }^{47}$

The second step of the argument is that in accepting a role as the addressee of a complaint, the organization strengthens its autonomy from the member states. Not only is its ontological existence secured, it is also the case that the organization maintains the screen (the institutional veil) between it and its member states. ${ }^{48} \mathrm{It}$ may well be the case (though need not be) that organizations are controlled by some member states or act under instructions by some states, but by being positioned as separate actors, their autonomy from their member states is asserted and confirmed.

This may seem like stating a truism, but there is an important point here: an international organization may be granted formal legal personality and therewith autonomy from its member states, but if such is never confirmed or even asserted it will become a 'dead letter'. Put in more principled terms: organizations can exist in the eyes of the law if this is provided for in a legally relevant document, but it will need the occasional practical invocation in order to be sustained in the long run, in much the same way in which legally binding treaties can come to be terminated through the process of desuetude, or existing customary rules can be overruled by new practices. These may be slow processes, and relatively rare, but not entirely implausible. ${ }^{49}$

Instead of being a truism, though, the point points to an inevitability (or, more accurately perhaps, a relative inevitability), and it goes something like this. International organizations are set up on a voluntary basis; under Enlightenment conditions, this is considered necessary so as to align their existence with the existence of sovereign states. Those states can as an emanation of their free will ${ }^{50}$ decide to pool their resources, but only if they consent thereto. Likewise, individuals are taken, for purposes of international civil service law, as sovereign entities, whose consent is required - anything else would amount to forced labour, bondage, or slavery. As a result, legal and ethical argument needs to take this seriously: member states, third parties, and international civil servants all can claim some moral autonomy and should not be confronted with acts that are forced on them. Thus, discussions on expulsion of member states, or dismissal of staff members, or even on legal protection of organizations themselves through privileges and immunities, need to respect this moral autonomy. ${ }^{51}$

On these premises, there are only two types of argument available. One is an argument that the relevant party has broken a particular and applicable rule, or has otherwise not acted in accordance with a duty it had itself accepted. Legal obligations resting on international organizations cannot be picked from thin air, as a general proposition, but stem from conventions and headquarters agreements accepted by international organizations, from constitutional documents concluded between member states, and from employment contracts (or

\footnotetext{
${ }^{47}$ The US would actually withdraw from UNESCO some thirty years later, amidst charges of mismanagement and corruption by UNESCO's leadership. For brief discussion, see Yves Beigbeder, Management Problems in United Nations Organizations: Reform or Decline? (London: Frances Pinter, 1987).

${ }^{48}$ The leading conceptual study is Catherine Brölmann, The Institutional Veil in Public International Law: International Organisations and the Law of Treaties (Oxford: Hart, 2007).

${ }^{49}$ See e.g. E.W. Vierdag, Oorlogsverklaring (inaugural address, University of Amsterdam, 1992), discussing how treaties can fall into disuse if never applied even in circumstances where application is called for.

${ }^{50}$ See the Case of the SS Lotus, [1927] Publ. PCIJ, Series A, No. 10.

${ }^{51}$ Reportedly some voices within the UK, including the esteemed Lord Lugard, seriously considered to invite the US to undertake an intervention in Liberia. League members were bound by the Covenant but the US, so it was thought, as a non-member of the League could act freely without violating any contractual bond between it and Liberia. As reported in Von Gretschaninow, Der Versuch, at 175.
} 
administrative decisions ${ }^{52}$ ) consented to by international civil servants, all freely entered into. This, in turn, is premised on the idea that individuals, states and international organizations are all rational actors, pursuing their own interests with a certain vim and vigour.

And yet, pursuing one's own interests may entail that common interests are neglected; these fall by the wayside while everyone maximizes their own utility. As a result, somehow legal and ethical argument needs to use these resources as well, for surely otherwise the unmitigated pursuit of rational self-interest might affect the interests of others, if not now then quite possibly in the future. Even the patron saint of the regulatory function of the 'invisible hand', Adam Smith, realized all too well that the invisible hand could only do its magic work under specific conditions, something most competition authorities translate into doctrines about 'abuse of a dominant position' or similar devices. Hence, in addition to duty-based arguments, claims also tend to refer to the benign consequences of what is proposed, or the possibly devastating consequences if the 'slippery slope' is embarked on. It is not just the case that UNESCO's Mr Duberg had a consent-based duty to act in particular manner, it is also the case that if he were allowed to act as he pleased, all hell would break loose. Liberia was said to have violated not only a consent-based obligation to treat native inhabitants justly, but if it would be allowed to get away with not doing so, the League would lapse into something undesirable. And the UN is not only entitled to immunity from suit due to the presence of consent-based legal rules, it is also a mechanism that allows the UN to work effectively and without disturbance. Rule-based or duty-based arguments rarely stand alone; they are usually accompanied by warnings about the consequences.

The net result is that as a consequence of this interplay between deontology and consequentialism, itself necessitated by the (usually implicit) assumption about the moral autonomy of all relevant actors, the only possible thing that can happen is that legal and ethical disputes, for all their interminability, end up confirming the autonomy of the organization. Within the parameters of debates on the premise of the moral autonomy of all relevant actors, there is no escape: assuming moral autonomy results in confirming moral autonomy, including that of international organizations, and any conclusion to a moral or legal dispute remains vulnerable to criticism. The decision to uphold the UN's immunity will not satisfy those who advocated that immunity be lifted, as their arguments are not seriously met, only mirrored. The decision not to expel Liberia (a decision never formally taken) does little to satisfy the arguments of those who advocated expulsion; and the decision to invalidate the dismissals of Mr Duberg and his colleagues does little to appease the UNESCO bosses and their fears of creeping communism. By staying within the same register, the arguments are bound to be each other's reflection, and disagreements literally interminable. The only reason to consider the disagreement as terminated is not because one claim is stronger than the other on its merits, but because an authoritative person or organ (typically a court or tribunal) makes a decision. In such a setting, there are only two possible escape routes.

The first of these is to give up all pretenses relating to the moral autonomy of actors. If states or international organizations do not have to be assumed to be morally autonomous, no harm will be done if things are imposed upon them, and if so, no harm will be done if legal rules are broken in the process - if there would be legal rules to begin with in such a setting (as opposed to coercion, to 'might being right'). Some of the

\footnotetext{
${ }^{52}$ Amerasinghe notes that some organizations use contracts, while others use administrative decisions to regulate labour relations. In both cases though what is relevant is the consent of the civil servant. See C.F. Amerasinghe, The Law of the International Civil Service, $2^{\text {nd }}$ edn (Oxford University Press, 1994).
} 
traditional 'so-called 'realist' literature on international relations contains traces hereof ${ }^{53}$, doubting the moral autonomy of international organizations while upholding that of states, but this was never credible ${ }^{54}$ and has come to be questioned even by its own practitioners. ${ }^{55}$

The second escape route is different in nature, and premised on a dual notion. First, moral autonomy is not disregarded, but focused on the individual. After all, states and international organizations alike are not merely impersonal bureaucratic structures, but are composed of individuals and, more importantly perhaps, managed by individuals. The UN may well be the UN, but its character at any given moment in time is partly determined by the identity of the Secretary-General and other high-ranking officials. It is not for nothing that many tend to think that the UN under Hammarskjöld was a different creature from the UN under Waldheim, say, or BoutrosGhali. It is arguable that the influence of individuals is limited, hemmed in by structures and rules and constituencies, and partly determined by the situations in which these individuals find themselves. Hammarskjöld, it might be suggested, could leave a legacy because he found himself running an organization paralyzed by the Cold War. The point is, though, that he managed to exploit the power vacuum between the two opposing superpowers in ways that others have proved unable to do, and it is here, in the margins of management, that personality comes to matter.

Second, then, legal and ethical argument can shift to (or be complemented by) an appeal to what can be expected from individuals in the professional roles they occupy. Often this is not so much a matter of whether rules are being violated - and this is not even always easy to identify. Rules can be manipulated; rules can leave discretion; rules can be in conflict with one another; rules can even, on occasion, be completely absent. In such cases, it may matter how persons in a position of leadership come to act, and especially on what basis they come to act. Launching a military intervention to test new weapons systems at the expense of thousands of lives is not a good idea; launching the same intervention, at the same expense, for the purpose of saving many other lives might just about be justifiable. Deontology and consequentialism have little room for the proper motivation of ethical behavior ${ }^{56}$, but a focus on motivation and the propriety thereof can be derived from Aristotelian virtue ethics.

This is not the place to further develop a virtue ethics framework; suffice it to say that the legal literature, including the international law literature, contains some hints to this effect, some more explicit ${ }^{57}$ than $^{\text {others }}{ }^{58}$,

\footnotetext{
${ }^{53}$ And has sadly found some echo in relatively recent writings by international lawyers, conjuring up a world exclusively populated by states where international organizations do not exist or, when they do, play no role whatsoever: see Jack Goldsmith and Eric Posner, The Limits of International Law (Oxford University Press, 2005).

${ }^{54}$ At least not since the emergence of international organizations in the latter third of the nineteenth century has it been plausible to regard organizations as epiphenomenal, which is not to deny that organizations can be vehicles for particular interests. A fine study is Craig Murphy, International Organization and Industrial Change: Global Governance Since 1850 (Cambridge: Polity, 1994).

${ }^{55}$ See e.g. Tana Johnson, Organizational Progeny (Oxford University Press, 2014), proudly proclaiming to be initiating a paradigm shift in the field of international relations by providing international organizations with a role (and moral autonomy) of their own.

${ }^{56}$ This was one of the pivotal points inspiring Anscombe's classic critique: see Elizabeth Anscombe, 'Modern Moral Philosophy', reproduced in Roger Crisp and Michael Slote (eds.), Virtue Ethics (Oxford University Press, 1997), 26-44.

${ }^{57}$ Colin Farrell and Lawrence Solum (eds.), Virtue Jurisprudence (New York: Palgrave MacMillan, 2008); Amalia Amaya and Ho Hock Lai (eds.), Law, Virtue and Justice (Oxford: Hart, 2013); Jan Klabbers, 'The Virtues of Expertise', in Monika Ambrus et al. (eds.), The Role of 'Experts' in International and European Decision-making Processes: Advisors, Decision Makers or Irrelevant Actors? (Cambridge University Press, 2014), 82-101.

${ }^{58}$ Koskenniemi's appeal to a 'culture of formalism' can be understood as a virtue-based approach. It is developed in Martti Koskenniemi, The Gentle Civilizer of Nations: The Rise of Modern International Law 1870-1960 (Cambridge University
} 
and these have in common that their initial focus rests not so much on acts (maligned or otherwise), but on the actors performing them in their professional roles: as government lawyers or judges, as directors-general, as policy experts, as mediators.

This has several advantages from an evaluative perspective. First, by acknowledging that decision-making is in part a function of the individuals making the decisions, it allows for moral dilemmas to be taken seriously. Such dilemmas are plentiful, for instance due to the circumstance that rules may be conflicting, and different constituencies may have different yet equally legitimate concerns as far as consequences are concerned. The perennial discussion about the World Bank and human rights may constitute an example: deontological lawyers (almost a pleonasm ${ }^{59}$ ) insist that the World Bank should not engage in the violation of human rights ${ }^{60}$; their economist colleagues, trained consequentialists, fundamentally do not grasp the point if it can be demonstrated that certain policies may be overall beneficial. ${ }^{61}$

Second, it allows for the termination of ethical debate. If the above is correct in that deontological and consequentialist argument feeds off each other and engage each other in a continuous loop, a focus on character and virtue may help debate reach a conclusion: should, for instance, the World Bank decide arrogantly to embark on a particular project because of the prestige involved in it, then surely it is doing something wrong, regardless of whether in doing so it violates any rules or whether the activity leads to nefarious consequences. Doing something solely for reasons of prestige is by no means rare, but it is not particularly virtuous. In Maclntyrean terms, doing so focuses on the goods external to a practice, whereas one should ideally be motivated by the pursuit of goods internal to a practice. It would be like playing chess in order to become rich, rather than out of an appreciation of the challenges of the game; it would be like becoming a film producer in order to force girls (or boys) into sex, rather than out of appreciation for the art. ${ }^{62}$

And third, a partial shift to the virtues may help to evaluate the absence of behaviour. International organizations are established with a certain function in mind, but often enough, they do not act when an appeal on their function would make us expect action - the UN inaction in Rwanda in 1994 is perhaps the most painful example. ${ }^{63}$ In the absence of strong rules ordering organizations to act, the only yardstick left is to analyze the inaction and the motivations behind it in light of the organization's mandate. ${ }^{64}$

\section{Final Remarks}

Press, 2001). See further Jan Klabbers, 'Towards a Culture of Formalism? Martti Koskenniemi and the Virtues', (2013) 27 Temple International and Comparative Law Journal, 417-435.

${ }^{59}$ Few international lawyers self-identify as consequentialist: a prominent example is Steven Ratner, The Thin Justice of International Law (Oxford University Press, 2015).

${ }^{60}$ Although, to prolong the earlier analysis: others may point to conflicting rules embedded in the World Bank's constitutional instrument (a deontological point), or that violating human rights can never lead to good consequences, as it fatally undermines respect for human dignity and thus opens the door for all sorts of abuses (a consequentialist point).

${ }^{61}$ Galit Sarfaty, Values in Translation: Human Rights and the Culture of the World Bank (Stanford CA: Stanford University Press, 2012).

62 Maclntyre, After Virtue, at 190-191.

${ }^{63}$ See Michael Barnett, Eyewitness to A Genocide: The United Nations and Rwanda (Ithaca NY: Cornell University Press, 2002).

${ }^{64}$ See further Jan Klabbers, 'Reflections on Role Responsibility: The Responsibility of International Organizations for Failing to Act', (2017) 28 European Journal of International Law, 1133-1161. 
This article has suggested that the autonomy of international organizations need not be invoked as principle of international organizations law in order to materialize. Instead, legal and ethical debate invoking duties and consequences will inevitably see to it that the autonomy of the organization is confirmed and strengthened, for the same reason that acts of non-recognition are philosophically paradoxical: an explicit non-recognition tends to do precisely what it explicitly negates. ${ }^{65}$ As long as legal and ethical debate oscillates between duties and consequences, there is no terminus: a deontological debate can always be met with a consequentialist critique, and vice versa. Hence, one either has to ignore the moral autonomy (the extra-contractual freedom) of actors altogether, or change register, for instance by resorting to the virtues, in order for ethical and legal debate to be conclusive.

The one remaining question then is what a move to the virtues entails with respect to the autonomy of international organizations, and it would seem the answer is rather similar. A reference to the UN under Hammarskjöld is still a reference to the UN, even if behaviour is attributed to Hammarskjöld. This follows from his professional role: he is not acting in his private capacity, but representing the UN - and it can be anticipated that in that capacity his acts do not always coincide with the acts of private citizen Hammarskjöld. The philosophy of action has established that when people change roles, they do not change their identities and characters ${ }^{66}$, but different roles entail different responsibilities, different constituencies, different activities. It is plausible that Dag Hammarskjöld the Swedish civil servant would have taken different decisions in that capacity than he would have done as UN Secretary-General, even on the same issues, simply because his different professional role would have prompted different attitudes.

The virtue perspective does, however, allow for a nuance: since the UN under Hammarskjöld may differ from the UN under, say, Waldheim, it is acceptable in debates to point to these differences, in much the same way that individuals can point to their own development: from young people other things are expected than from older people; youthful indiscretions may be forgiven, whereas the same behavior in older people invites condemnation. That is not to say that the maturity metaphor should be taken seriously: the life of an international organization does not progress in the same way as that of an individual, and should not be expected to do so. The suggestion here is merely that under different leadership, the same legal entity will display different types of behaviour, and some leaders will strive to be more autonomous vis-à-vis member states than others. ${ }^{67}$

Be that as it may, it seems reasonably clear that the autonomy of international organizations vis-à-vis their member states benefits from engaging in debate on the legality or ethical propriety of what the organization does or even what it represents, analogous to the classic Public Relations slogan that 'there is no such thing as bad publicity'. It would seem that there is some merit in adopting a virtue perspective in addition to more traditional perspectives, but doing so is unlikely to affect the autonomy of the institution in any measurable way.

${ }^{65}$ Which is why the law needs to specify the legal effects attaching to acts of non-recognition.

${ }^{66}$ See, e.g., G.A. Cohen, 'Beliefs and Rôles', (1967) 67 Proceedings of the Aristotelian Society, 17-34; R.S. Downie, Roles and Values: An Introduction to Social Ethics (London: Methuen \& Co., 1971)

${ }^{67}$ Waldheim is usually portrayed as a Secretary-General keen to please the powerful member states, and thus less interested in institutional autonomy than some of his predecessors or successors. See, e.g., Simon Chesterman (ed.), Secretary or General? The UN Secretary-General in World Politics (Cambridge University Press, 2007). 
